\title{
六/6: Finding Meaning. The Expanded Exhibition and the Post-Pandemic World
}

\author{
Andrea Lorenzo Baldini \\ Nanjing University, China \\ andrea.baldini@nju.edu.cn
}

\begin{abstract}
How will artistic exhibitions function in the post-pandemic world? Visiting museums and galleries is a health hazard. 六/6: Finding Meaning is an attempt to offer an alternative. It embodies a novel exhibiting format called the expanded exhibition, which inhabits an expanded public space, between the physical and the digital. 六/6 shows us that, once liberated spatially, exhibitions can be effective tools of meaning-making and social change even in a post-pandemic world. By exploiting the interplay between the digital and the physical domains, expanded exhibitions such as 六/6 can build alternatives of cultural production that can cope with social distancing, while being participatory, democratic with respect to access, and politically transformative by displacing the colonialist hierarchy centre/periphery.
\end{abstract}

Keywords: museum, digital exhibition, participatory art, street art, periphery

To cite this article:

Baldini, A. L. (2020) 六/6: Finding Meaning. The Expanded Exhibition and the Post-Pandemic World, The Journal of Public Space, 5(4), 30I-3I2, DOI I0.3289I/jps.v5i4.I382

This article has been reviewed by the Editors and accepted for publication in The Journal of Public Space.

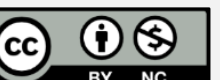

This work is licensed under a Creative Commons Attribution - Non Commercial 4.0 International License https://creativecommons.org/licenses/by-nc/4.0/ 


\section{Introduction}

What is the future of cultural production and consumption? Traditional exhibition venues such as museums and galleries are public spaces designed to bring people together, and often in great proximity to one another. For this reason, they are perfect places for virus spreading, which amidst the explosion of the COVID-19 pandemic have been generally shut down (Solomon et al., 2020). In the foreseeable future, their use will be likely restricted. Moreover, limitations on traveling will make it difficult to visit the most important artistic hubs such as the Venice Biennale or Art Basel.

As a consequence of these changes in accessing post-pandemic public spaces, there is a nagging question about the future of art and its experience: How will artistic exhibitions function? 六/6: Finding Meaning is an attempt to answer that question in practice (Fig. I). Developed and realized in collaboration with Pietro Rivasi, students from two of my classes at Nanjing University, and an international group of artists, it is arguably the first specimen of what I shall call the expanded exhibition, that is, an exhibition inhabiting an expanded public space, between the physical and the digital.

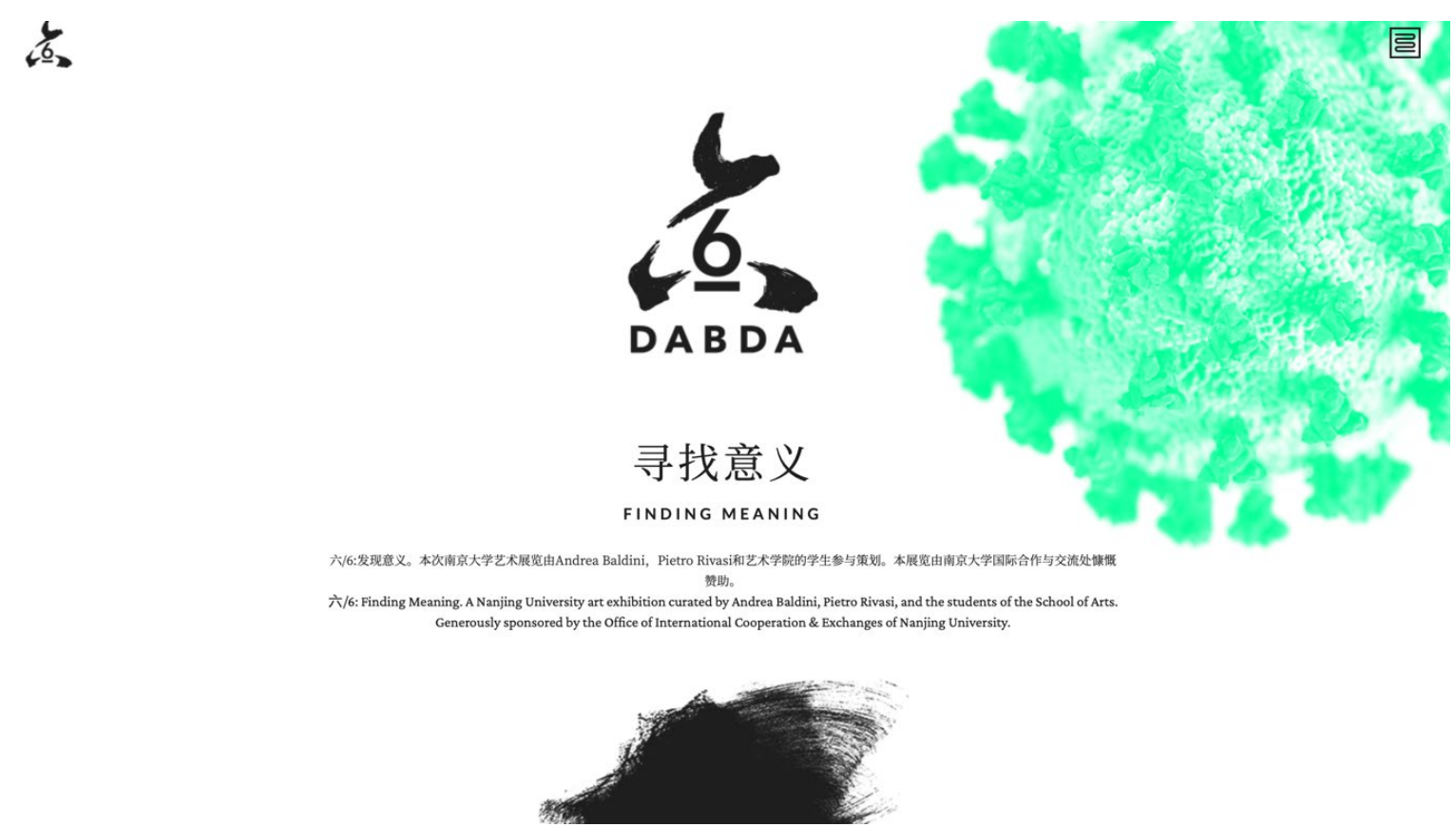

Figure I. A Detail of the homepage of 六/6: Finding Meaning. Screenshot by the author.

六/6 shows us that, once liberated spatially, exhibitions can be effective tools of meaning-making and social change even in a post-pandemic world. In effect, by exploiting the interplay between the digital and the physical domains, expanded exhibitions such as 六/6 can build alternatives of cultural production that not only can cope with a need for social distancing, but that are also participatory, democratic with respect to access, and can be politically transformative by displacing a center/periphery hierarchy. These exhibitions can offer an extended forum of reflection, which in the case of 六/6 was

\footnotetext{
' https://findingmeaning.art
} 
meant to facilitate processing our pandemic trauma, while possibly challenging exclusionary trends in cultural production and consumption.

\section{Finding Meaning in Grief}

The story of 六/6 started in the early March 2020, when I was teaching online. A few days before a class held via Zoom, I read about an official Chinese project to collect mementos and artifacts from the country's battle against COVID-19 (Fig. 2). It inspired me to rethink my students' final assignments: Rather than write another term paper, I had them curate an exhibition dedicated to the pandemic, a kind of collective personal diary of those difficult months. After some brainstorming, we came up with a theme: $\frac{\text { 六 }}{4}$ 16: Finding Meaning - a reference to the stages of grief we were all experiencing.

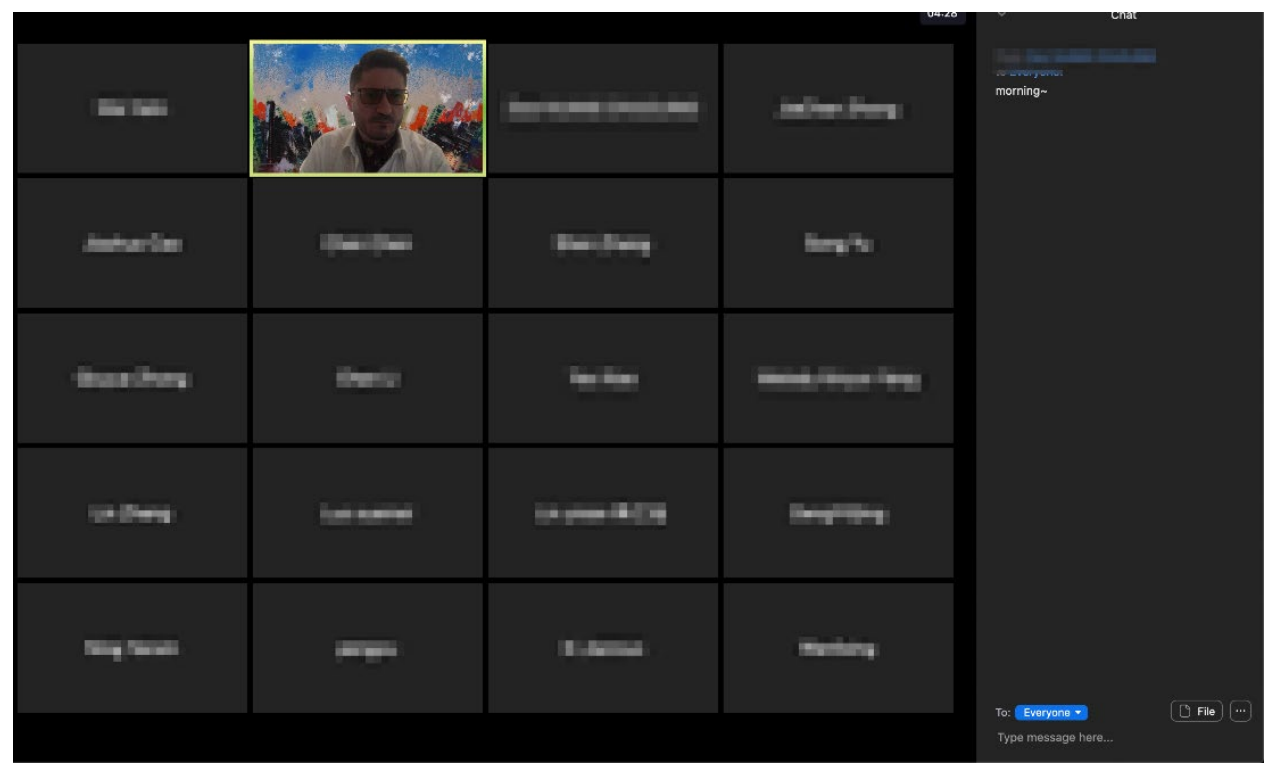

Figure 2. Online Class during Spring '20. Screenshot by the author.

Kübler-Ross (2005) introduces the seminal theory of the five stages of mourning: denial, anger, bargaining, depression, and acceptance. Within the literature, Kübler-Ross's theory has been linked with death. Yet, as long-time Kübler-Ross collaborator David Kessler emphasizes, life gives us many reasons to grieve, from a loss of normalcy or economic difficulties to simple isolation. We face loss also when we experience "the end of a marriage, the closing of the company where we work, the destruction of our home in a natural disaster" (Kessler, 2019: 10).

Kübler-Ross's theory of grief became our exhibition's organizing principle. One of the virtual rooms, "DABDA" (Denial, Anger, Bargaining, Depression, Acceptance), consists of objects that, in the experiences of my students, connect with one of those stages, helping us express our suffering (Fig. 3). The possibility of bottom-up design and content creation is one of most interesting possibilities unleashed by the spatial liberation that digital technologies unleash. Students here, scattered all across China and very far from 
my location, were capable to tell their own stories, with a level of creative freedom that is difficult to imagine in more traditional settings.

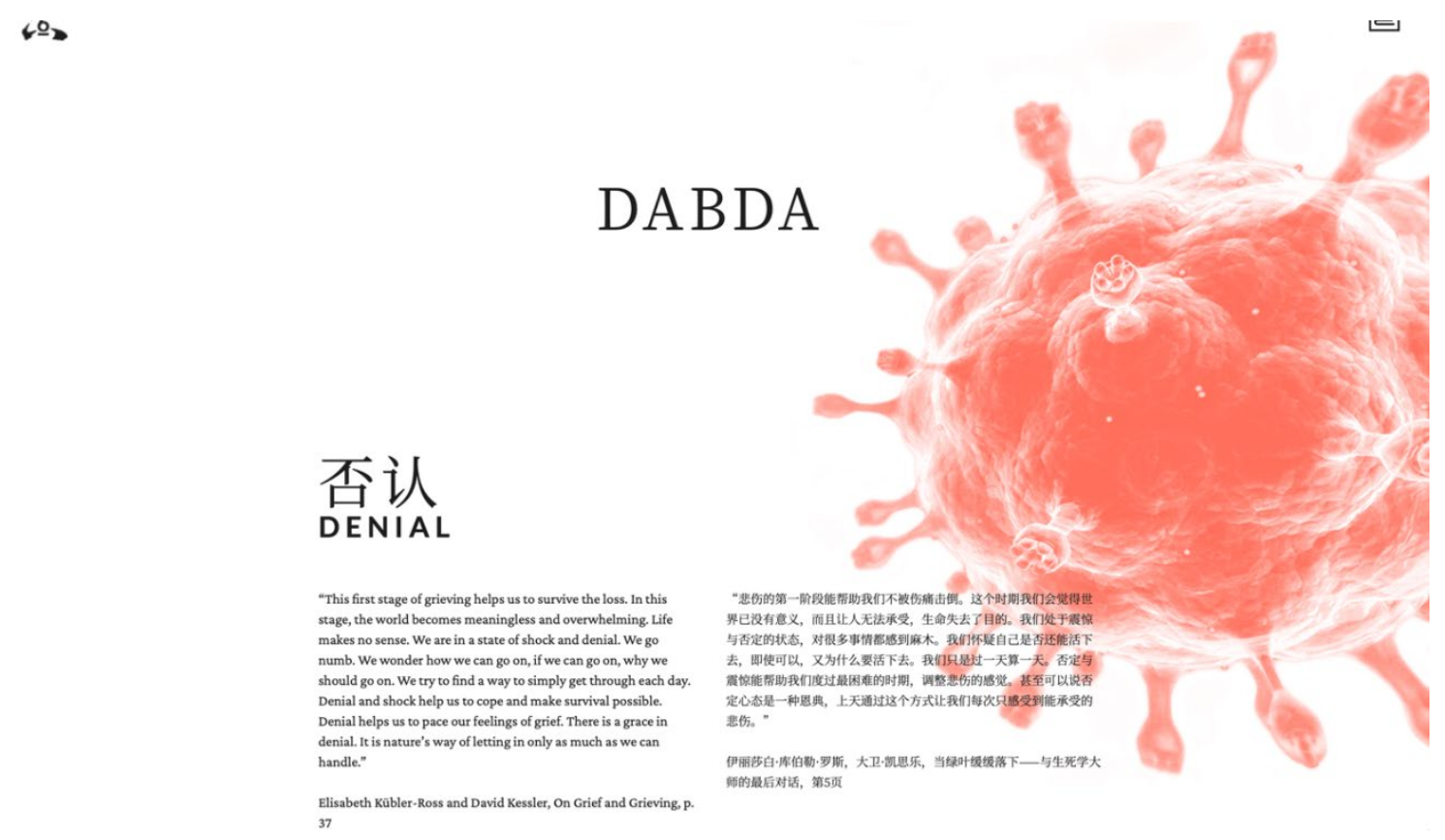

Figure 3. The landing page of "DABDA." Screenshot by the author.

Students did not merely describe their circumstances, but - in some cases spontaneously created artworks that were instrumental to express their complex emotional states. This is true, for instance, for Wan Lixing, who created a collage and an installation to articulate in the medium of artistic transformation her own anger. The collage is a repetition of the same picture capturing her annoyance at virtual reality's inauthenticity (Fig. 4).

The installation expresses her frustration against those who did not wear facemasks in public spaces (Fig. 5).

To the usual five stages of grief, Kessler (2019) adds a sixth one, which was crucial to our plans: meaning. Dissatisfied with the idea that acceptance is the end of the healing process, Kessler was convinced that to become whole again we must first find meaning in the darkness that envelops us. At a time like this, that could be as simple as realizing not all is lost, and that we can still express agency. We called our project $\frac{1}{\mathrm{i}} / 6$ : Finding Meaning as a reference to Kessler's final stage of grief, but the repetition of the Chinese and Arabic numerals - besides creating a graphic sense of universality and inclusivity also echoes the Chinese expression liuliu dashun: "May everything go smoothly." The artists involved in the project donated some of their works, which were explicitly designed for this occasion and sometimes involved the participation of our students (Fig. 6) or that of visitors (Fig. 9). 
RESISTING VIRTUAL REALITY AND

DECEPTION

By Wan Lixing

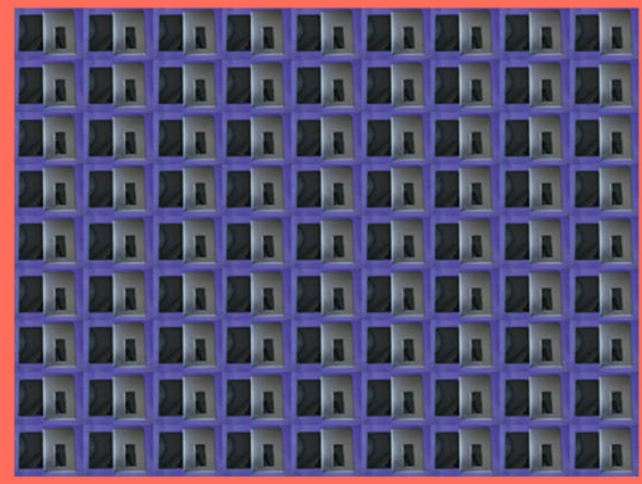

This collage is a repetition of the same picture, representing my phone, my tablet, and my computer. In the days of the lockdown, only those objects gave me access to the outside world, breaking with their colorful screens the humdrum reality that I was living in. But that is the virtual world after all: Day after day, the confinement into the virtual world deepened rather than relieve my depression. What started out as a way of seeking out

companionship, just turned out to be a copy-and-paste version of reality. When I realized this, the virtual world stopped to give me comfort, but rather unleashed my inner rage: I needed the real

world, I didn't want to be entrapped in the deception of the virtual realm anymore. 欺缩。
抵制虚拟和欺骗

万里行
这顿作品是由同一蝠昭片复制拼㕷而成的，代表我的手机、平板和由 膀。因为疫情而无法出门的日子里，只有这些东西才能让我接触外面 的世界，用他们的彩色屏幕打破我生活的单调。但这毕竟是是虚扯的

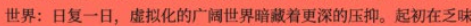
的日常生活中给予人们陪伴的电子产品终究成为了无数虚像的复制数 贴，当我意识到这一事实后，电子产品给予我的不再是安䍐与陪伴， 而是无限的压抑和内心的暴怒，我需要真实的自然，而不甘于被虚像

\section{恐惧}

FEAR

By Wan Lixing

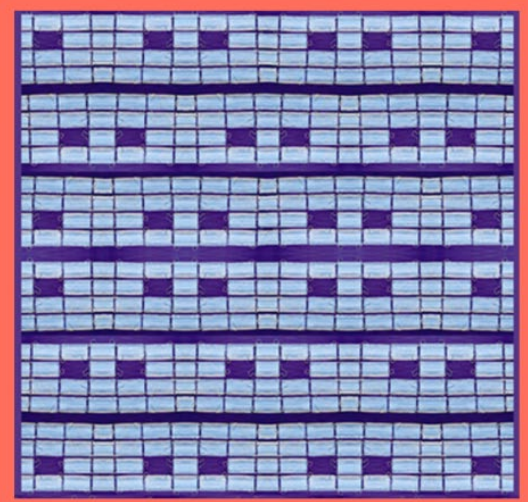

This installation is made up of arrangements of clusters of 4 by 4 masks, where one of the masks is missing. This wants to represent what we all witnessed during the pandemic. Though most people were wearing masks, some were not. I was angry at those people in response to the fear that I was experiencing. I was too afraid to say something, to come forward - the only thing that I could do was covering up my face, while burying my anger deep down in my heart.
我将口翌摆成 $4^{\star} 4$ 的矩阵, 中间有一块是空缺的。我再将这个矩阵图 拼贴翻折，组成一张密布着口算却有些许空缺的拼贴画，以此象征疫

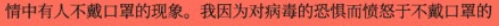
人们，也因为恐惧而不敢上前指责。我唯一能做的，只是紧紧捂紧口 翠, 把我的渍怒蔵在心里
Figure 4. Wan Lixing's collage. Screenshot by the author.
Figure 5. Wan Lixing's "facemasks" installation. Screenshot by the author. 

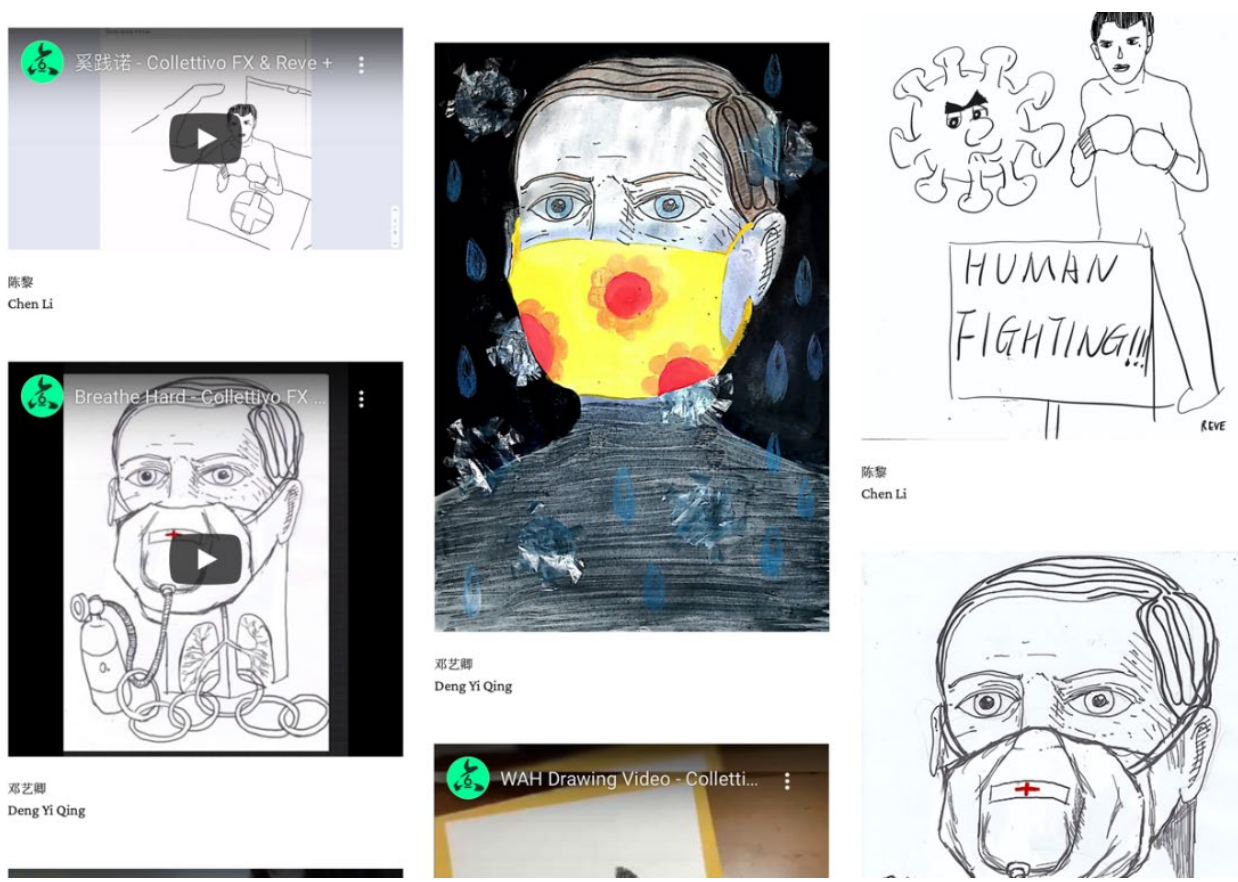

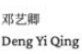

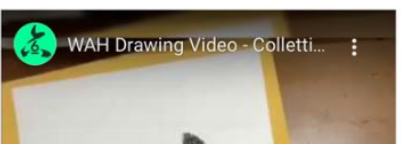

陡然

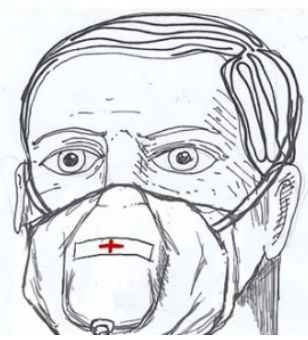

Figure 6. Detail of Collettivo FX's and Reve+'s page in "六/6"presenting their participatory project DisegniComuniCanti. Screenshot by the author.

We collected artists' donations in a virtual room called “六/6," a space where we can metaphorically and metonymically conquer our pain and find meaning in our suffering through the medium of artistic transformation (Fig. 7).

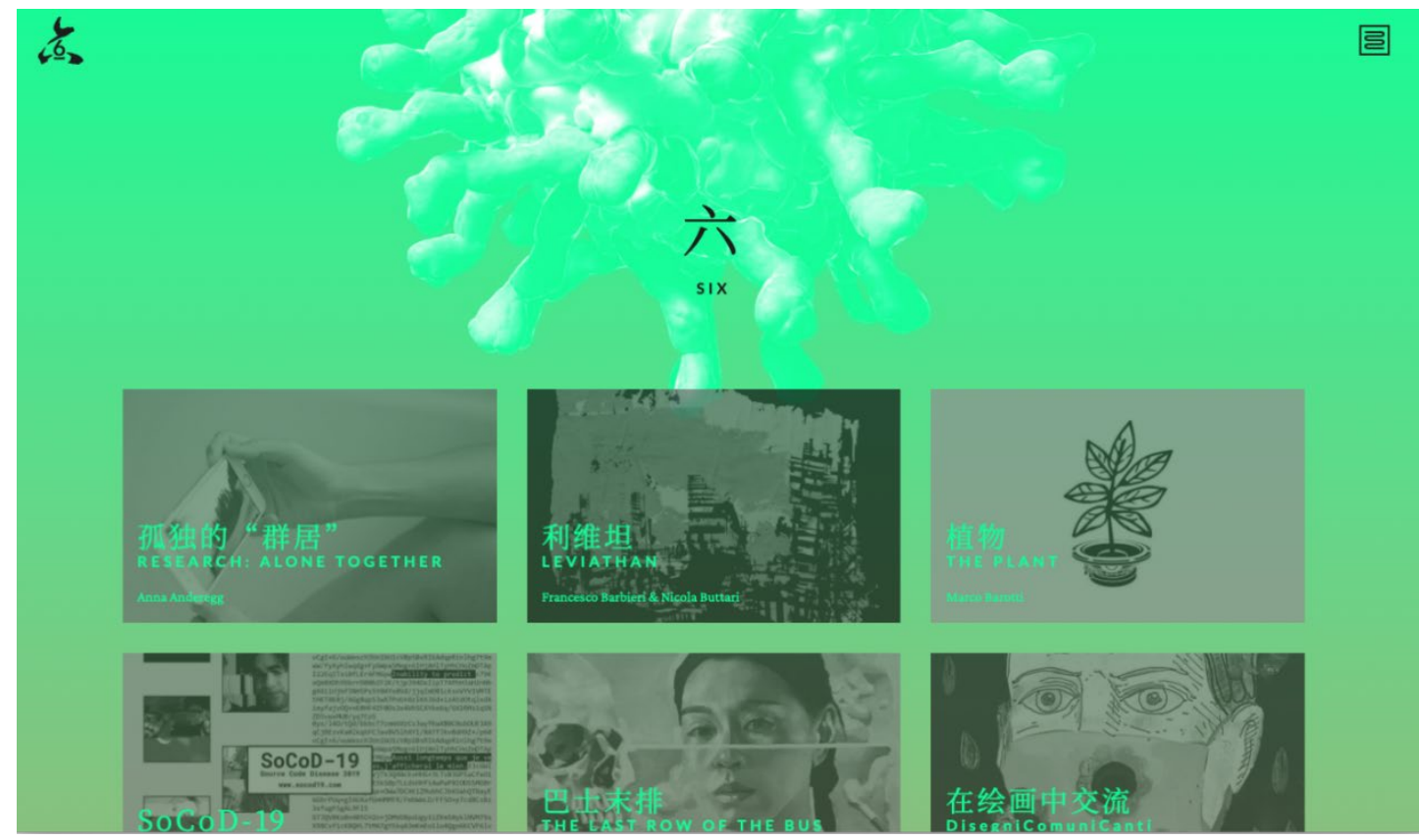

Figure 7. A Detail of the landing page of "六/6." Screenshot by the author. 
There is another room: "Emotional Timeline." Here, a group of students, in collaboration with Italian duo Biancoshock \& Rolenzo, artistically re-interpreted the timeline of the pandemic. It consists of a reproduction of this year's fluctuations in the Shanghai stock market, manipulated to reflect students' emotional states during that time. Before the pandemic, economic forces could seem laws of nature. But COVID-19 showed how something as small as a virus can upend them.

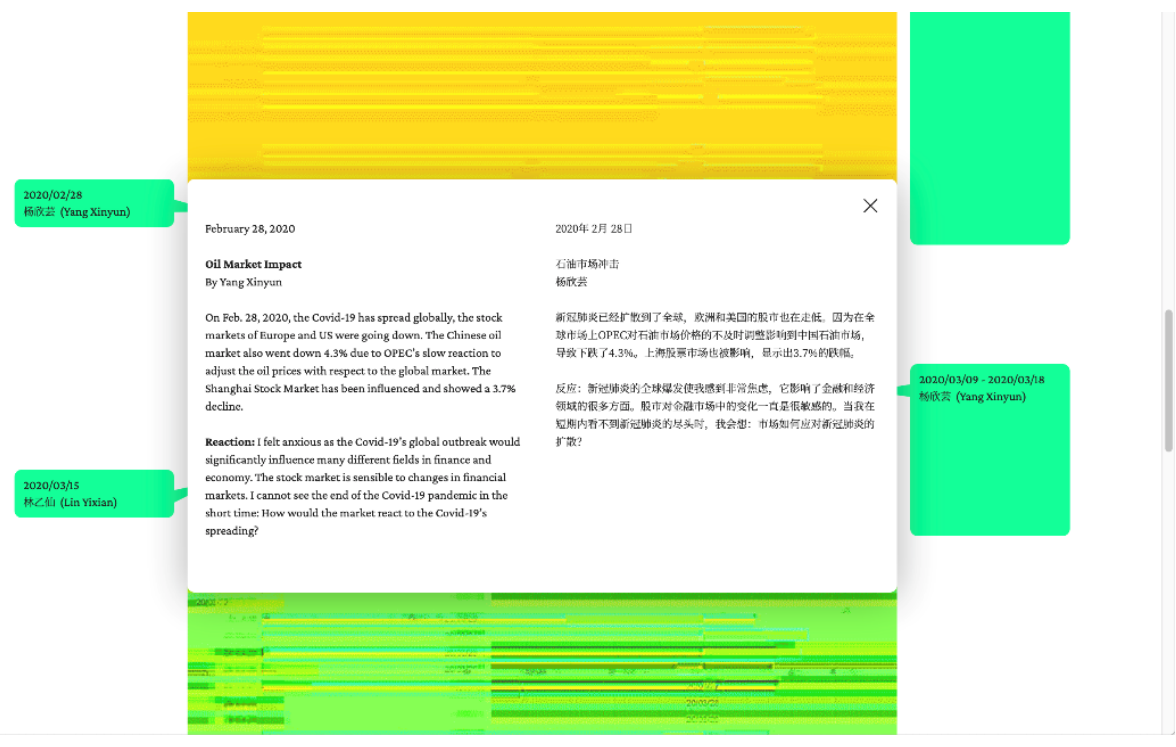

Figure 8. Detail of "Emotional Timeline." Screenshot taken by the authors.

The peculiarity of $\frac{1}{\wedge} / 6$ is, as mentioned before, its expanded nature. In other words, what I have described so far focuses primarily on its digital side. However, the project is designed to make a ripple in the physical domain through a series of further developments, which are open ended and partially ground its socially transformative possibilities. ${ }^{2}$ In the following section, I discuss why we opted for the expanded model.

\section{Expanding the Exhibition's Space}

In response to national lockdowns, many cultural institutions - including very prestigious ones - have turned to the world of the internet to keep feeding viewers' aesthetic hunger, while avoiding risks of contagion. Digital exhibitions have since then taken the podium. Though some welcome this trend without qualification (Pogrebin, 2020), others are more cautious: Virtually visiting a digital exhibition seems to lack of something(s) that we experience when physically engaging with art. ${ }^{3}$ In developing 六/6, both artists and students expressed their skepticism about traditional format of digital exhibitions. Their perceived incapacity to restructure how we use public spaces and live our lives was the main object of criticism: "virtual visits resemble too much video games," many artists and collaborators were lamenting.

\footnotetext{
${ }^{2}$ A press intends to publish a book including the content of the exhibition.

${ }^{3}$ https://www.debatingeurope.eu/2016/03/31/viewing-art-online-diminish-experience/\#.Xte7TsZS_Y0
} 
Visiting a physical exhibition, in effect, does not merely stimulate our senses. It also modifies, among other things, how we practice metropolises, cities, towns, villages, etc. This in turn has also an impact on travelers' routes, influencing when, where, and how we travel. Attending the opening of a physical exhibitions, for instance, can also structure community building by somewhat guiding the people we meet, the friends we make, and the people we fall in love with. Contrary to what Modern theories of art want to tell us, experiencing art at exhibitions does not disengage us from our daily concerns, but rather opens up new possible scenarios of everyday life. ${ }^{4}$ Exhibitions therefore enter the domain of human action by re-describing uses of public spaces while shaping how we act, think, and feel. ${ }^{5}$

By being incapable of affecting how we practice public spaces, digital exhibitions seem to structurally lack in that transformative aspect, that is, in its capacity to shape our daily lives. By drawing on Lopes (2009) one could plausibly argue that an event is a digital exhibition just in case (I) it is an exhibition ${ }^{6}(2)$ made by computer or (3) made for display by computer or other digital device (tablet, smart-phone, e-reader, etc.) (4) in a common, digital code. As such, a digital exhibition does not take us physically anywhere: It allows us to surf the virtual realm and, at best, introduce us to online communities. ${ }^{7}$

Surely dominant models of digital exhibition suffer from the limitations just highlighted: Both what I shall call the documental exhibition and the virtual tour cannot significantly shape how viewers practice public spaces, thus failing to touch upon their everyday lives (Champion, 2014). On the one hand, documental exhibitions take as their model archives, and present a combination of pictures of artifacts combined with text - or other explanatory add-on. ${ }^{8}$ On the other hand, virtual tours create game-like immersive experiences, which can become very realistic through the use of VR technologies (Bekele et al., 2018). ${ }^{9}$ Both categories of digital exhibitions can surely afford some value(s), but they offer surrogate experiences that are self-contained within the boundaries of the virtual domain, failing to have a deep impact on our non-digital identities.

六/6 was designed to contrast these limitations while still profiting from the advantages in terms of accessibility, participation, and social distancing that documental exhibitions and virtual tours afford. Those difficulties follow primarily from thinking virtual and material spaces as essentially distinct. But this is far from a necessity. There is no ontological separation between virtual and material spaces. They can stand in a symbiotic relationship creating the conditions for the emergence of an interplay between the digital and the physical domains, and our project intended to exploit those possibilities.

But how to create such an interplay? 六/6 as an example of expanded exhibition looks at street art as an inspiration. This urban art kind produces meaning and shape our lives among other things - by exploiting the interaction between the virtual and the material

\footnotetext{
${ }^{4} \mathrm{I}$ am broadening a claim defended in Baldini (2016)

${ }^{5}$ Here, I am suggesting that exhibitions are akin to real metaphors (Feagin, 1996; Summers, 1991).

${ }^{6}$ The question of what is an exhibition raises concerns that I cannot consider here. For a pertinent discussion, see Ventzislavov (20l4)

${ }^{7}$ As far as I know, major digital exhibitions or museums do not generally offer services of online community building.

${ }^{8}$ For an example, see https://artsandculture.google.com/partner/the-j-paul-getty-museum?hl=en.

${ }^{9}$ For an example, see https://artsandculture.google.com/partner/the-british-museum.
} 
(Baldini, 2020). Since the mid-2000s, street artists have begun to use the internet, and in particular that of social media, in ways that significantly links it with material reality. Street art does not simply provide its aficionados with virtual galleries of interesting visual artefacts, but it restructures how we practice spaces. It invites us to explore neglected parts of the city in search of the latest graffiti (Rivasi, 2017). In some cases, street artists can even reshape routes of global tourism (Morgan, 2020). In 六/6, we followed three principles in establishing the connection between the virtual and the material space that we see in street art: (i) expanded conceptualization; (ii) democratic digital access; and (iii) localized materialization. Let me discuss them in turn. First, expanded conceptualization requires from both curators and artists to think about the exhibition and the individual artworks as ontological hybrids jointly inhabiting the digital and the physical spaces. 六/6 realizes this principle by being imagined as a digital exhibition with physical manifestations and vice versa. This in turn has forced both Rivasi and I to envision certain spatial hierarchies and arrangements of content that would have not emerged if thinking only in terms of a digital or traditional exhibition. By forcing artists to create an ontological hybrid, this requirement has showed new creative directions. For instance, Biancoshock and Rolenzo have reimagined their digital project SoCoD-1 9 (Fig. 9) in the expanded space as an artist book including the pictures and texts that users have uploaded and written in the original website.
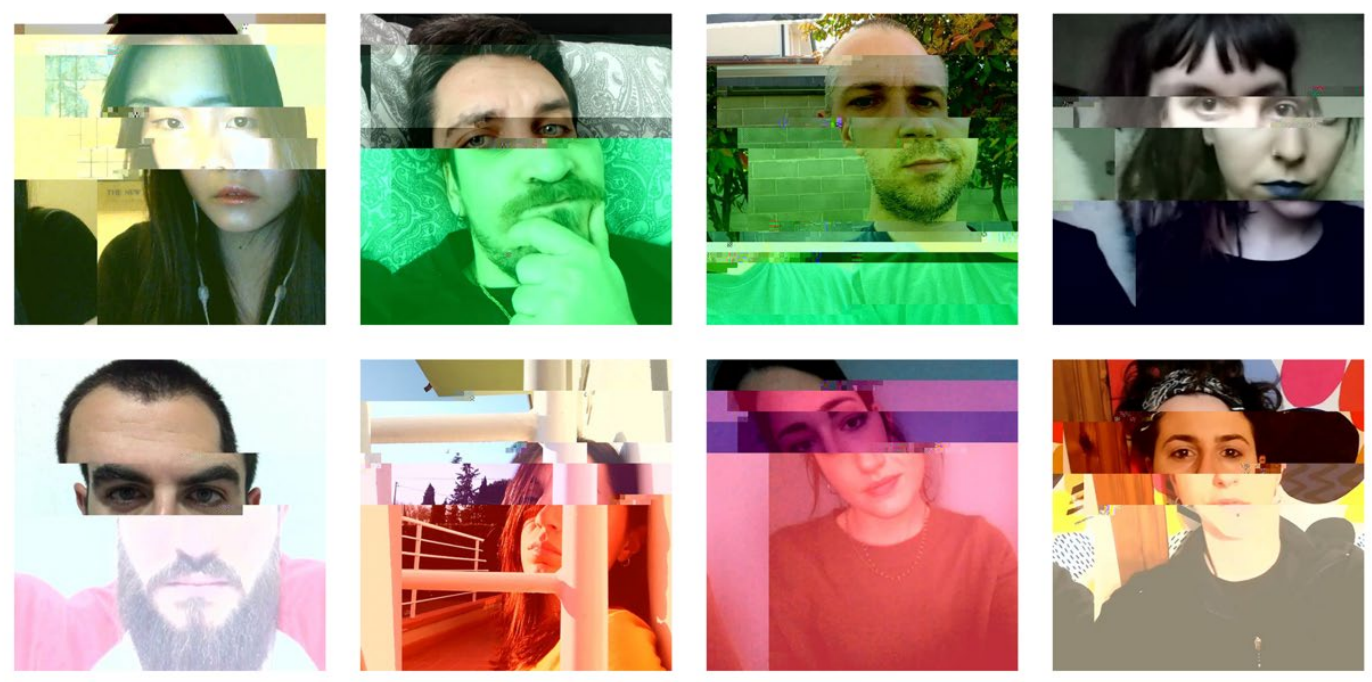

Figure 9: Detail of Biancoshock's and Rolenzo's page in "六/6" presenting SoCoD-19. Screenshot taken by the author.

Since the beginning, we laid out a proposal that we shared with artists according to which Plastique Fantastique's MOBILE PPS for Doctors (Fig. 10), a "bubble" designed to protect visitors from getting infected, would offer the spatial framework for physical instantiations of the exhibition. In early 2020, we expect to have exhibitions in Modena (Italy) and Nanjing (China), thanks to the efforts of our partners Associazione Culturale Stòff and Nanjing University. 

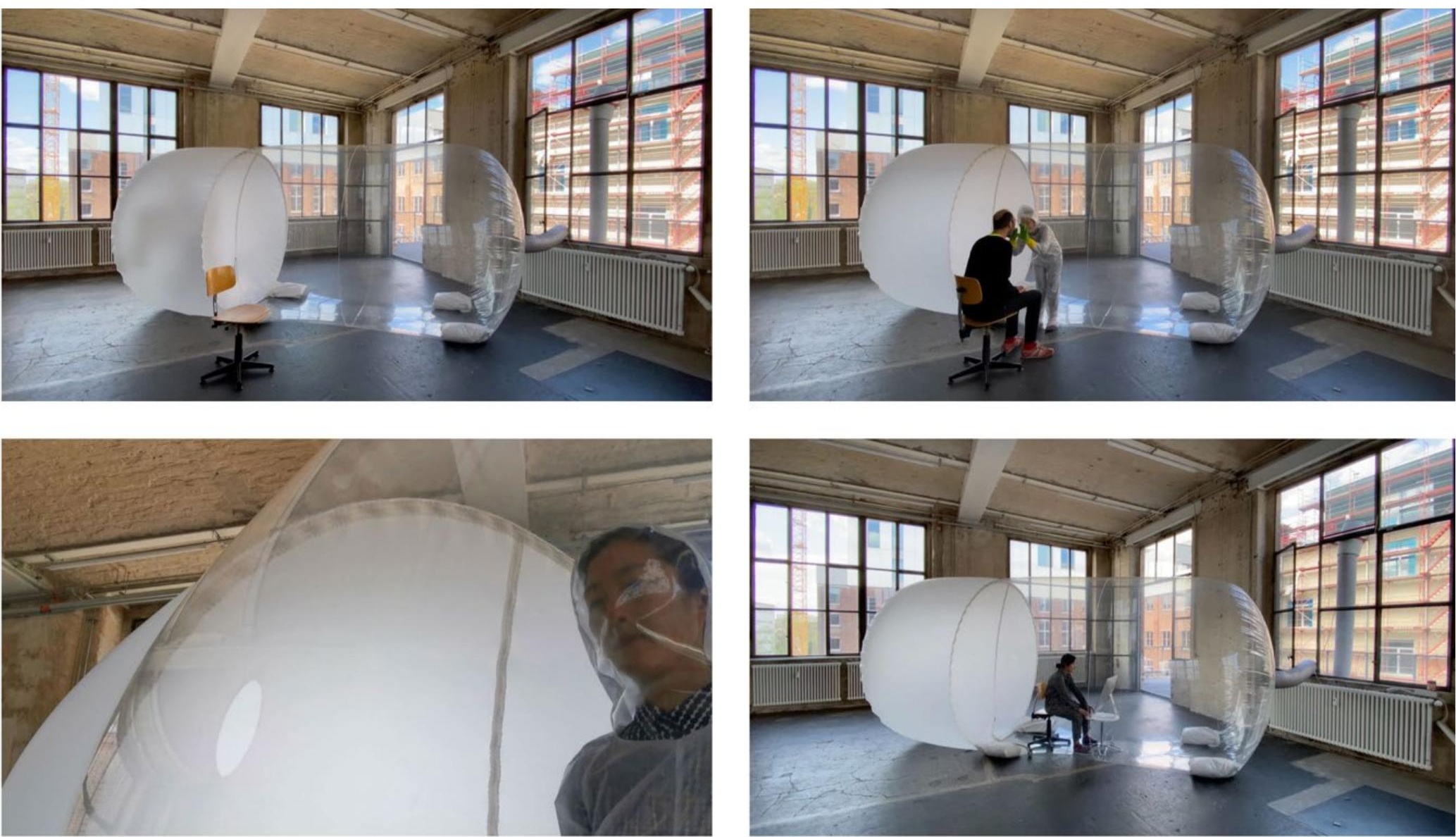

Figure 10. Detail of Plastique Fantastique's page in "六/6" presenting Mobile PPS for Doctors. Screenshot taken by the author.

Second, the democratic digital access is instrumental in promoting inclusivity, while counteracting exclusionary tendencies found in traditional exhibitions. 六/6 uses a basic technology. Artists' works have also favored accessibility over fancy digital tricks. For instance, in creating Chaos del Tri per uno (Fig. I I), Italian artist Gerardo Paoletti has decided to limit his tarots' interactivity as to avoid excluding users with older smart-phones.

Third, localized materialization deals most directly with the approach to the transubstantiated side of expanded exhibition. It is an approach that wants to displace the hierarchy center/periphery and its colonial implications by promoting a plurality of instantiations (Kaps and Komlosy, 2013). This in turn is the most critical and socially transformative aspect of 六/6 and the expanded exhibition. It deconstructs in practice the myth of the artist and the curator, dissolving their authorities by materializing without the on-site intervention of the original creative team.

This approach empowers local communities, which can create everywhere an exhibition. In doing so, they question the need for established artistic centres, which usually are global metropolises such as New York, London and Shanghai - while effectively coping with travel restrictions. In六/6, local materialization meant going fully modular. For artists, the main challenge has been to envision works that can be assembled on-site without their direct 
supervision. For instance, Marco Barotti's Plant uses a design that can be recreated by any suitable expert in robotics (Fig. 12).

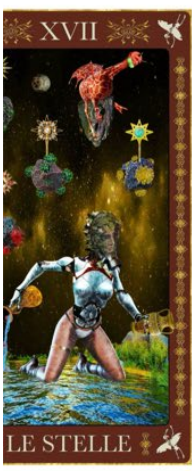

(Le Stelle)

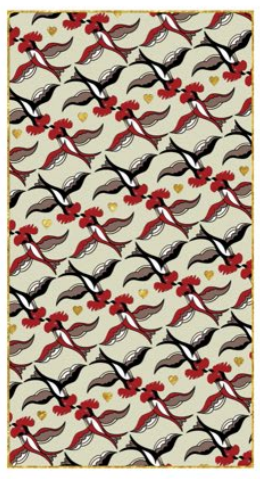

塔罗牌背面

Backsterisen

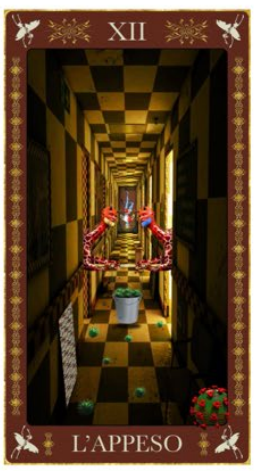

倒挂者
The Hanged Man (L'appeso)

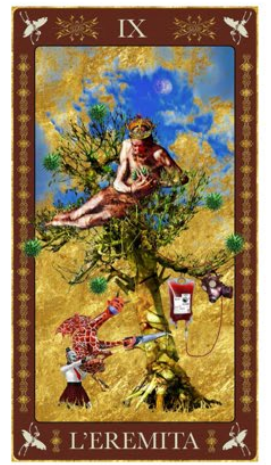

眐土

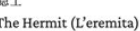

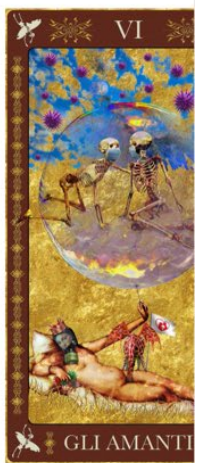
The Lovers (Gli amanti)

Figure II. Detail of Gerardo Paoletti's page in "六/6" presenting Chaos del Tri per Uno. Screenshot taken by the author.

调查研究: 技术进展、数据转换、超声处理 RESEARCH: TECH DEVELOPMENTS, DATA TRANSLATION, SONIFICATION
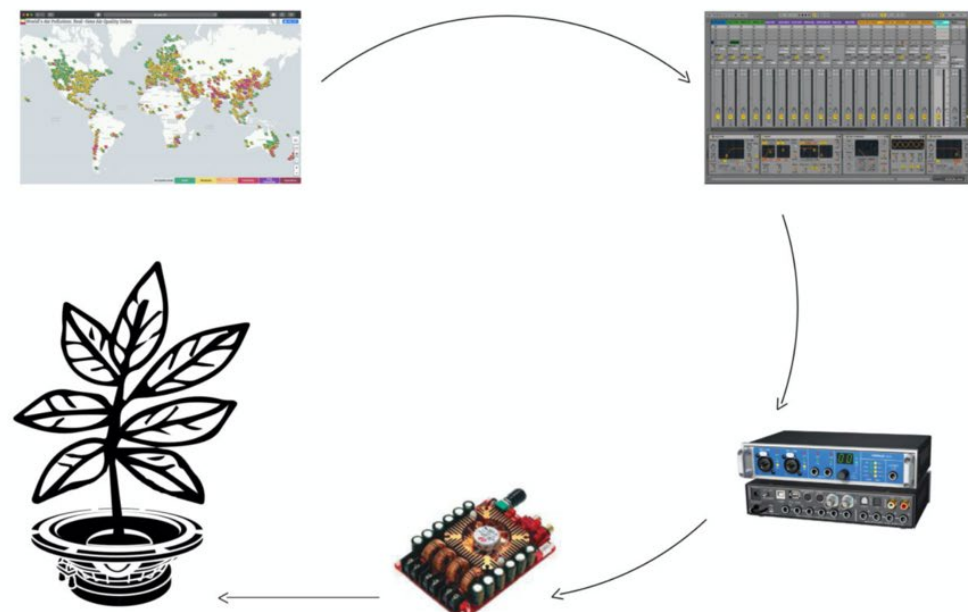

Figure 12. Detail of Marco Barotti's page in "六/6" presenting The Plant. Screenshot taken by the author.

How will artistic exhibitions function? I suggested an answer that sees cultural production in post-pandemic world as taking place in the expanded space, that is, a space in between the digital and the physical domains. When exploiting their interplay, expanded exhibitions will shape how we practice the everyday in ways that could also counteract exclusionary tendencies that often afflict traditional cultural consumption and production. The space of culture needs to be expanded, not simply replaced. 


\section{Acknowledgement}

六/6: Finding Meaning is available at https://findingmeaning.art and was generously sponsored by the Foreign Affair Office of Nanjing University, and supported by the School of Arts of Nanjing University and the NJU Center for Sino-Italian Cultural Studies. Partner institutions include Associazione Culturale Stòff; MoCu Magazine; Vicolo Folletto Gallery; Uniser, University of Pistoia. Participating artists include Anna Anderegg; Francesco Barbieri \& Nicola Buttari; Marco Barotti; Biancoshock \& Rolenzo; Filippo Cardella; Collettivo FX \& Reve+; Gianni Lucchesi; 罗蔷 (Luo Qiang); Edoardo Malagigi; Gerardo Paoletti; Plastique Fantastique; 杨然 (Ran Yang); 汪华 (Vigi Wang); 宗宁 (Zong Ning).

\section{References}

Baldini A (2016) Street art: A reply to Riggle. The Journal of Aesthetics and Art Criticism 74(2): 187191.

Baldini A (20I7) Dangerous Liaisons: Graffiti in da Museum. In: Un(Authorized)//Commissioned. Rome: WholeTrain Press, pp. 26-32.

Baldini A (2020) Street Art in the Digital Age: Photos, Documents, Urban Agency. ArchDaily. Available at: https://www.archdaily.com/933982/street-art-in-the-digital-age-photosdocuments-urban-agency (accessed 4 June 2020).

Bekele MK, Pierdicca R, Frontoni E, et al. (2018) A Survey of Augmented, Virtual, and Mixed Reality for Cultural Heritage. Journal on Computing and Cultural Heritage I I (2): 7: I-7:36. DOI: I0.1 |45/3 |45534.

Champion E (2014) History and Cultural Heritage in Virtual Environments. In: Grimshaw M (ed.) The Oxford Handbook of Virtuality. Oxford, New York: Oxford University Press. DOI: 10.1093/oxfordhb/9780199826162.001.000I.

Feagin SL (1996) Paintings and Their Places. Australasian Journal of Philosophy 73(2): 260-268. DOI: $10.1080 / 000484095$ I234659I.

Kaps K and Komlosy A (2013) Centers or Peripheries Revisited: Polycentric Connections or Entangled Hierarchies? Review (Fernand Braudel Center) 36(3-4): 237-264.

Kessler D (2019) Finding Meaning: The Sixth Stage of Grief. New York: Scribner.

Kübler-Ross E (2005) On Grief and Grieving: Finding the Gift of Grief through the Five Stages of Mourning. New York: Scribner.

Lopes DM (2009) A Philosophy of Computer Art. New York: Routledge.

Morgan R (2020) A new side to the holy city of Bethlehem. In: BBC Tarvel. Available at: https://www.bbc.com/travel/story/20200406-a-new-side-to-the-holy-city-of-bethlehem (accessed 4 June 2020).

Pogrebin R (2020) Art Galleries Respond to Virus Outbreak With Online Viewing Rooms. The New York Times, 16 March. Available at: https://www.nytimes.com/2020/03/I 6/arts/design/art-galleries-online-viewingcoronavirus.html (accessed 3 June 2020).

Rivasi P (2017) Photography for urban art. In: Reggiane. Reggio Emilia: Corsiero, pp. 20-27.

Solomon CS Tessa, Selvin C and Solomon T (2020) See a List of Coronavirus-Related Closures at Museums Around the World. In: ARTnews.com. Available at: https://www.artnews.com/art-news/news/coronavirus-museum-closures-worldwide1202680933/ (accessed 3 June 2020).

Summers D (199I) Real Metaphor. In: Bryson N, Holly MA, and Moxey K (eds) Visual Theory: Painting and Interpretation. New York, NY: Harper Collins, pp. 23 I-259.

Ventzislavov R (2014) Idle Arts: Reconsidering the Curator. The Journal of Aesthetics and Art Criticism 72(I): 83-93. 